\title{
Correction to: Morpho-cultural and pathogenic variability among isolates of Stemphylium vesicarium (Wallr.) E. Simmons, causing Stemphylium blight in onion collected from different geographical regions of Kashmir valley
}

\author{
Mudasir Hassan $^{1}$ - Vaseem Yousuf ${ }^{1}$ - Z. A. Bhat ${ }^{2}$. N. A. Bhat ${ }^{1} \cdot$ T. A. Shah ${ }^{1} \cdot$ M. A. Khan ${ }^{3} \cdot$ R. R. Mir ${ }^{3}$. \\ Roaf Ahmad Rather ${ }^{1}$. Safoora Shafi ${ }^{3}$
}

Published online: 22 July 2020

(c) Indian Phytopathological Society 2020

\section{Correction to: Indian Phytopathology \\ https://doi.org/10.1007/s42360-020-00253-8}

The article Morpho-cultural and pathogenic variability among isolates of Stemphylium vesicarium (Wallr.) E. Simmons, causing Stemphylium blight in onion collected from different geographical regions of Kashmir valley, written by Mudasir Hassan, Vaseem Yousuf, Z. A. Bhat, N. A. Bhat, T. A. Shah, M. A. Khan, R. R. Mir, Roaf Ahmad Rather, Safoora Shafi, was originally published electronically on the publisher's internet portal (currently SpringerLink) on
31 May 2020 open access. With the author(s)' decision to step back from Open Choice, the copyright of the article changed July 2020 to $\odot$ Indian Phytopathological Society 2020 and the article is forthwith distributed under the terms of copyright.

Publisher's Note Springer Nature remains neutral with regard to jurisdictional claims in published maps and institutional affiliations.

The original article can be found online at https://doi.org/10.1007/ s42360-020-00253-8.

Mudasir Hassan

hmudasir72@gmail.com

1 Division of Plant Pathology, Faculty of Agriculture, Sher-e-Kashmir University of Agricultural Sciences and Technology of Kashmir, Wadura, Sopore, India

2 Division of Plant Pathology, Faculty of Horticulture, Sher-e-Kashmir University of Agricultural Sciences and Technology of Kashmir, Shalimar, Srinagar, India

3 Division of Genetics and Plant Breeding, Faculty of Agriculture, Sher-e-Kashmir University of Agricultural Sciences and Technology of Kashmir, Wadura, Sopore, India 